\title{
CRIMINAL THREATS FOR PERPETRATORS OF OMISSION IN CHILD ABUSE IN INDONESIA
}

\author{
Lina Dwi Istiqomah \\ Diponegoro University \\ lina.dwi100@gmail.com \\ Nyoman Serikat Putra Jaya \\ Diponegoro University \\ Putrajaya1948@yahoo.co.id \\ Duwi Aryadi \\ Diponegoro University \\ Duwiaryadi24@gmail.com
}

\begin{abstract}
Child abuse is increasingly happening every day. Even cases of child abuse are mostly perpetrated by parents. Many people who know, but those who do know just tend to leave and seem unconcerned because of the notion that violence is not their problem. There is also an assumption that violence against children is one of the methods of education given by parents to children. So it is not right for other parties to interfere in the problem of educating children. The existence of these assumptions makes people become indifferent and allow violence. The problem is there is a criminal threat for those who allow child abuse. In this article the normative legal approach is to use literature or literature studies and qualitative descriptive analysis of the problem. This research shows the ignorance of the public regarding the threat of crime because of acts of omitting violence against children which is known to make child violence increase and have a greater impact in the future. Regarding the omission of violence against children itself has been regulated in Article 78 of the Child Protection Act, whereby anyone who does not allow violence against children can be subject to criminal threats.
\end{abstract}

Keywords: Abandonment of Violence; Child; Criminal Threats;

\section{A. INTRODUCTION}

Criminal activity plaguing the society, then such actions should be dealt with firmly, and it is the duty of the law which has the function to create and maintain order and all in community life, as the adage "ubi societas ibi ius", (in where there are people there is the law). Type any criminal offense, which is a criminal offense or crimes like murder or such violations, and there is a mention of crime/criminal acts such as theft and minor crime patterned, everything must be done prosecution. The offender must obtain criminal sanctions in accordance with his deeds. However, such a crime, offense or offenses patterned minor crime having different sanction of course, and a minor crime patterned criminal offenses can not be equated 
with a criminal sanction criminal acts which cause serious injury to the victim. ${ }^{1}$

Children are a gift from the Almighty God who must be well cared for and protected. Children are also the successors of a nation that will change the world in the future. As a gift of God that must be taken care of, the child certainly has rights that must be fulfilled and should not be taken away from him. According to Law No. 39 of 1999 on Human Rights (Human Rights Law) there are several rights of children, among them are the right to protection, the right to be raised, maintained, cared for, educated, directed and guided, the right to legal protection, and the right so as not to deprive him of his freedom against the law.

The efforts of protecting children must be initiated as early as possible, in order to participate optimally for nation and country development. In Article 2 paragraph (3) and (4) of the Act of no. 4 Year 1979 on Child Welfare, states that: "Children are entitled to the maintenance and protection for the womb or after birth. Children are entitled to environmental protection which may endanger or impede growth and development in a natural way. ${ }^{2}$

1 Andri Winjaya Laksana, Sisca Dyah Octaviani, Implementation Of Law Enforcement Against Crime With Small Motive Patterned Restorative Justice In Police Sector Gayamsari Of Semarang City, International Journal of Law Recontruction, Volume III, Issue 1, March 2019, P.20-34.

2 Achmad Sulchan, Zakki Mubarok, The Roles Of Investigator In Implementing Diversion On Children Criminal Action, International Journal of Law Reconstruction, Volume II, Issue 1, March 2018, P.41-52
In addition to the Human Rights Act, children's rights are also included in Act No. 35 of 2014 concerning Amendments to Act No. 23 of 2002 concerning Child Protection (Child Protection Act), including the right of children to live in growth and development and participate and get protection from violence and discrimination, the right to be free from violence and violence in the injustice and mistreatment and other mistreatment, and every child who is a victim or perpetrator of a a criminal offense is then entitled to get legal assistance and other assistance. Before the existence of the aforementioned law, there was also the Convention on the Rights of the Child (CRC) which had been ratified by Indonesia through Presidential Decree Number 36 of 1990 which specifically regulates everything concerning children's rights. Reflecting on this CRC, children are holders of basic rights and freedoms as well as those who receive special protection. The Convention on the Rights of the Child was also born from a realization that children in accordance with their nature are natural, dependent, innocent, and have special needs. Therefore children need special care and protection, both physical and mental. $^{3}$

The existence of arrangements regarding child protection certainly makes it clear that children must be free from violence and other bad things. But nowadays violence against children is increasing in number, both

3 Rini Fitriani, Peranan Penyelenggara Perlindungan Anak Dalam Melindungi Dan Memenuhi Hak-Hak Anak, Jurnal Hukum Samudra Keadilan 11, no. 2 (2016), P.250358 , 
violence against children committed by parents or other adults and even violence committed by fellow children themselves. In the Child Protection Act, "violence is any act against a child which results in physical, psychological, sexual or / or misery or neglect, including threats to commit acts, coercion or unlawful deprivation of liberty". Another understanding of violence is according to WHO, "violence is the use of physical force and power, threats or actions against oneself, individuals or groups of people or communities that cause or are likely to result in bruises/trauma, death, psychological harm, developmental disorders or deprivation of rights". ${ }^{4}$

Violence in children that occurs can be done by parents themselves, the environment and even fellow children. Many parents think that violence against children is a natural thing as part of a method of educating and disciplining children. The violence is considered as learning because it is intended as a punishment or sanction if the child does something wrong. The results of research in one of the journals that have been published states, the highest cause of parents committing violence against children is to discipline children. Most parents still commit violence with this purpose. ${ }^{5}$

The existence of cases of violence against children, especially

4 Thathit Manon Andini, Identifikasi Kejadian Kekerasan Pada Anak Di Kota Malang, Jurnal Perempuan Dan Anak 2, no. 1 (2019), P.13-28.

5 Dewi Eko Wati and Intan Puspitasari, Kekerasan Terhadap Anak, Penanaman Disiplin, Dan Regulasi Emosi Orang Tua, Jurnal VARIDIKA 30, no. 1 (2018), P.2126. those committed by their own parents, of course many of these cases are known by neighbors or surrounding communities. However, not all people or neighbors care about violence that occurs with the assumption that it is not their realm to interfere. People tend to let the violence they know and end up with violence that continues. Even though the community is one of the parties that must guarantee the fulfillment of children's rights. ${ }^{6}$

The community as one of the parties that must play a role to protect children and fulfill their rights should not be able to just ignore and allow an act of violence against children to occur. Aside from being reluctant to interfere, the community is also less aware of criminal threats and the effects of omission. So that in this study focuses on the omission of violence against children by the community.

The update in this paper is this paper discusses several factors of omitting acts of violence against children known to the community, the impact of omission and also an explanation of the presence or absence of criminal threats and any efforts that can be done so that the community can play an active role in tackling the amount of violence against children which happened that had never been written by other researchers, especially in the form of journals. Several journals exist, many of which discuss legal rules or criminal threats for perpetrators of acts of violence against children but not for

6 Ria Juliana and Ridwan Arifin, Anak Dan Kejahatan (Faktor Penyebab Dan Perlindungan Hukum), Jurnal Selat 6, no. 2 (2019), P.225-234. 
the inclusion of violence. In some online news, there have been discussions about criminal threats for perpetrators of violence against children, but only discussed one factor in the occurrence of omission and still have not been discussed further about other factors of omission and the effects of omission. The problem in this research is whether there is a rule of law that can ensnare those who commit such omission, or whether criminal threats can only be imposed on perpetrators of child abuse. This research will also discuss further about the factors of omission that occur and the threat of criminal sanctions for those who allow a criminal act of violence against them, also about any efforts that can be done so that people participate and play an active role to stop the occurrence of violence against children.

\section{B. REASEARCH METHODS}

The approach used in this paper is a normative juridical approach. A juridical normative approach is a legal research approach that is carried out by examining library materials or secondary data as a basis for research by conducting a search of the regulations and literature relating to the problem under study. ${ }^{7}$ Data analysis used in this study is descriptive-qualitative by analyzing data/information obtained through descriptive research with library research which is then systematically

7 Ahmad Rofiq, Hari Sutra Disemadi, and Nyoman Serikat Putra Jaya, Criminal Objectives Integrality in the Indonesian Criminal Justice System, Al-Risalah 19, no. 2 (December 16, 2019), P.179-190. compiled and described qualitatively. ${ }^{8}$ The data needed from this research is secondary data obtained from primary materials in the form of laws and regulations, secondary legal materials in the form of books, theses, journals and other literature, and also assisted with tertiary legal materials by searching related news both from the media print or online.

\section{DISCUSSION}

\section{Criminal Threats for Violating Violence Against Children}

Violence committed by parents against children is not only in the form of hitting the child until the child is bruised and physically injured, but also in the form of words such as screaming and swearing. ${ }^{9}$ Quoting from the results of research conducted by Eva Harianti and Nina Siti Salmaniah in Gunung Tua Village, Panyabungan District Mandailing Natal District through a questionnaire distributed about $15 \%$ of respondents knew about forms of violence perpetrated by parents against children, $32 \%$ of respondents answered only a few know, and as much as

8 Andi Aina Ilmih, Kami Hartono, Ida Musofiana, Legal Aspects of The Use Of Digital Technology Through Sharia Online Transactions In Traditional Markets In Increasing Community Economy, International Journal of Law Recontruction, Volume 3, Issue 1I, September 2019, P.114122

9 Islamia Ayu Anindia, Perlindungan Hukum Terhadap Perdagangan Anak Dengan Modus Pernikahan Dalam Perspektif Viktimologis, Litigasi 19, no. 1 (2019), P.89-115. 
$53 \%$ of respondents answered not knowing the forms of violence against children. Whereas in terms of knowledge about committing violence against children is a violation of the law, the results of the study stated that $23 \%$ of respondents knew, 37\% knew little and $40 \%$ answered they did not know. Ignorance of parents about any form of violence and ignorance about violence against children is one of the violations of the law is due to the paradigm of parents that children are the property of their parents so that parents feel entitled to children and free to treat children as they wish in accordance with the wishes of parents. ${ }^{10}$

Acts of violence against children do often occur. Even worse, the perpetrators of the violence came from the victim's own family, such as parents or teachers at school. ${ }^{11}$ Children who often get physical, emotional and economic violence spontaneously in parenting patterns will affect their small brain (subconscious). Children who initially get violent just stay quiet, when violence by parents is carried out repeatedly, the

10 Eva Harianti and Nina Siti Salmaniah, Faktor-Faktor Penyebab Terjadinya Kekerasan Orang Tua Terhadap Anak, JPPUMA Jurnal IImu Pemerintahan Dan Sosial Politik Universitas Medan Area 2, no. 1 (2014), P.45-57.

11 Laurensius Arliman.S, Perlindungan Hukum Terhadap Anak Yang Tereksploitasi Secara Ekonomi Di Kota Padang, Arena Hukum 9, no. 1 (2016), P.73-93. child will defend themselves and be aggressive. ${ }^{12}$ Violence is recorded by a child in his cerebellum. When a child reaches adulthood and he experiences mental stress that causes him to get angry, a small memory where the child is often violently triggers him to commit the same violence. The phenomenon of violence in the family seems normal, common and justified by culture. Scuffs and punches are often addressed to children by sheltering on the pretext so that children are disciplined and not spoiled. ${ }^{13}$ Such a paradigm which considers that the child is the property of his parents which he may be treated at will, but only with reasons that according to parents make sense. The paradigm is a paradigm that is wrong and wrong, assumes that children do not have their own rights, and must always be according to their parents. The existence of this paradigm triggers the omission of the community against violence against children that occurs around it. ${ }^{14}$

12 Sarno Setiawan et al., Community Empowerment on Establishment of Friendly-Village for Women and Children, Indonesian Journal of Advocacy and Legal Services 1, no. 1 (2019), P.5-22.

13 Ayu Setyaningrum and Ridwan Arifin, Analisis Upaya Perlindungan Dan Pemulihan Terhadap Korban Kekerasan Dalam Rumah Tangga (KDRT) Khususnya Anak-Anak Dan Perempuan, JURNAL MUQODDIMAH: Jurnal IImu Sosial, Politik Dan Hummaniora 3, no. 1 (2019), P.9-19. 14 Asla De Vega, Hapidin Hapidin, and Karnadi Karnadi, Pengaruh Pola Asuh Dan 
The omission in the Indonesian Dictionary means the process or method of letting that comes from the verb letting, which means not prohibiting, not caring. ${ }^{15}$ So neglect of violence that occurs in children is an act that does not prohibit or not care about the occurrence of violence or acts of harming children. Violence against children is often done by their own families, especially their parents, ranging from physical violence such as hitting, kicking, slapping, pinching and other forms of abuse from the mild to those that can cause the child to die, to sexual violence such as incest, rape, sexual exploitation. ${ }^{16}$ The impact of children who are victims of violence is suffering losses, not only material, but also immaterial, such as emotional and psychological shocks, which can affect the child's personality and future life. ${ }^{17}$ During this time many around us cases or acts of violence committed by parents or adults on children, but

Kekerasan Verbal Terhadap Kepercayaan Diri (Self-Confidence), Jurnal Obsesi: Jurnal Pendidikan Anak Usia Dini 3, no. 2 (2019), P.433-439.

15 Pusat Bahasa, 2008, Kamus Bahasa Indonesia, Pusat Bahasa Departemen Pendidikan Nasional, Jakarta, P.578.

16 Abu Huraerah, 2012, Kekerasan Terhadap Anak, Nuansa Cendekia, Bandung, P.78.

17 Nunuk Sulisrudatin, Meninjau Kasus Kekerasan Terhadap Anak Oleh Orangtuanya Dari Segi Kriminologis, Jurnal IImiah Hukum Dirgantara 6, no. 1 (2015), P. 19-29. deliberately left by those around who see it either his own family, neighbors or anyone who sees. Someone who sees the occurrence of acts of violence against the child but deliberately lets it be the same as he does not prohibit or not stop the act so that acts of violence against children occur. Though anyone who sees a crime has an obligation to stop and report.

Factors of neglect are the occurrence of violence against children is considered an internal family problem and inappropriate if outsiders interfere in other family problems. The false idea that children are the rights of parents (children as property) or children are the property of their parents in full so that parents have the right to do anything in the name of education and teaching of their children either because of past revenge, hopes, obsessions or a reason to make his child better and obedient despite violence. For example, parents give punishment to their children by hitting or drying in the sun or even a teacher who slaps a child because he is more aggressive to his friend. These actions are certainly considered as one of the actions that educate and discipline children. There is also an assumption that violence usually occurs in troubled families so that often people or neighbors and the surrounding community who see violence in 
the family actually move away due to fear that their children will also become problematic, also the fear of opening something that is considered a family disgrace. Because families who often fight have a higher level of violence against children compared to families without problems. ${ }^{18}$ Another factor that makes us reluctant to act when violence occurs, is that acts of violence experienced are felt to be normal, even considered as a process of educating a husband to his wife, or parents towards a child. "This assumption is related to the belief that the husband is the leader of the family, so he has the right to regulate (if necessary with violence) against his family members".

Acts of violence against children are often not easily revealed, because violence against children, especially within the family, is essentially personal. This is also supported by public perception that the problems that occur in the family are internal family problems and are not suitable for interference. This perception raises the silence or passivity of the community around children, so that the culture of physical violence against children continues and

18 Andrie Irawan, Batasan Penelantaran Rumah Tangga Dalam Perspektif Hukum Kekerasan Dalam Rumah Tangga Dan Hukum Perkawinan Indonesia, JURNAL Hukum Responsif 7, no. 2 (2019), P.100-109, the survival of children becomes more threatened. ${ }^{19}$ That way, violence in children will be completely revealed if the injury to the child's body has been seen and getting worse or after the child died. Sometimes even though people witness violence firsthand and even the condition of the child is full of wounds, they are left alone because they fear that they will get into trouble if they intervene so they prefer to pretend to not know or just be a spectator.

Act of omission when seeing acts of violence on children will certainly have many impacts, including the violence that occurs will continue to occur and will not stop until the child victims of violence suffered severe injuries or even until the child dies. Another impact is from the psychological side of the child, a child victim of violence when he was a child when he was growing up if the trauma caused by the violence is not handled properly it will lead to the child's desire for revenge. Because someone who has experienced acts of violence in his childhood will tend to do things that have befallen him to others, so that the chain of violence against children will not be broken. Children who have experienced violence need

19 Tedy Sudrajat, "Perlindungan Hukum Terhadap Hak Anak Sebagai Hak Asasi Manusia Dalam Perspektif Sistem Hukum Keluarga Di Indonesia," Kanun: Jurnal IImu Hukum 3, no. 2 (2011), P.111-132. 
extra love and attention from their environment. Concern and hospitality from relatives, friends and teachers is needed to help children overcome their trauma in order to organize their lives in the future.

In the Human Rights Act also stipulates that related to the protection of children must be done by parents, families, communities and countries. Paradigms of children belonging to parents must be changed immediately. For that we need the role of each party. Community awareness to help supervise and protect children also needs to be increased. If a neighbor hits his child, we must dare to reprimand and prevent him. Reflecting on this statement it is very clear that children are protected by law. Because one of the causes of violence that occurs in children is increasingly rampant, including the lack of awareness of the community around the victim so that omission occurs. The role of the environment is needed to be concerned with events that befall other families. If the environment dares to reprimand or prevent violence against children, it means that a future is saved. ${ }^{20}$

Violence is not only done by the child's parents, but it can also be done by people in his circle, so it is necessary to make the violence as much as

20 Nurini Aprilianda, "Perlindungan Anak Korban Kekerasan Seksual Melalui Pendekatan Keadilan Restoratif," Arena Hukum 10, no. 2 (2017), P.309-332, possible be prevented and overcome in the following ways: a.) Help children protect themselves, provide understanding to be careful careful of strangers and open to parents; b.) report to the authorities, if there is physical, psychological or sexual violence it is better to immediately report it to the authorities. It aims to immediately take further action against the suspect and reduce the same crime rate. As for the victims, they must immediately get medical assistance and support from their families. ${ }^{21}$

During this time the surrounding community who know of violence against children but deliberately omitting not all know that doing omission of a crime that he knows, is a violation of the law. Violence is a crime. The obligation for everyone to report to the police, if they know that a crime has occurred, even though Article 165 of the Criminal Code only mentions a few articles of crime. This is an effort to prevent the occurrence of a crime, because if not notified immediately then the person can be said to give someone a chance to commit a crime. Regarding whether someone

21 Fransiska Novita Eleanora and Andang Sari, Eksistensi Lembaga Perlindungan Saksi Dan Korban Dalam Memberikan Perlindungan Terhadap Anak Korban Eksploitasi Seksual," Supremasi Hukum: Jurnal Penelitian Hukum 28, no. 2 (2019), P.153-163. 
who is aware of a criminal offense can be subject to punishment or not, clearly the answer is that it can be subject to punishment, if the person does not report to the party concerned about the existence of a crime that he knows.

In Article 165 of the Criminal Code a criminal threat to someone who is aware of a crime but does not report it, which is a 9-month prison term or a Rp. 4,500. Child abuse is a criminal offense. When there are people who know of violence against children but do not report it or let it be, that person can be given a criminal threat. In some cases, children are abused for years by their own parents, where neighbors know but keep quiet. Violence committed by parents against children is often seen as a domestic problem. Referring to the Child Protection Act in Article 77 it is regulated that anyone who deliberately acts of discrimination and neglect that can cause a child to experience physical or mental illness can be sentenced to a maximum of five years in prison and fined a maximum of Rp.100 million. Then in Article 78 it is explained that the same punishment also applies to everyone who knows and deliberately leaves a child in an emergency situation including violence.

The assumption of violence against children committed by parents as an internal domain causes many who prefer to let than report to the authorities. Then there must be a change in mindset in society as discussed earlier that child protection is the responsibility of all parties. Basically, the existing legal rules regulate and demonstrate their efforts in eliminating violence against children, whether it is a criminal threat to perpetrators of violence or those who commit neglect. But unfortunately there are still so many people who do not know or even ignored. In 2015 the Minister of Social Affairs Khofifah had said that those who saw and were aware of acts of violence against children could report via telepon Sahabat Anak (Tesa) number 129. This shows a serious step by the Government in its efforts to stop the occurrence of violence against children, it's just that there are still many people who do not know, so that a comprehensive socialization is needed to make the community aware of the importance of protecting children from violence.

Violence against children is not only a matter of government and parents of children, but also the responsibility of every community. Therefore the community is expected to be more concerned and not hesitant to report to the authorities when they see the violence committed by an adult person against their child. Children must get guarantees 
of survival and security, so that children can grow and develop well and are far from various acts of violence that interfere with them.

\section{CONCLUSION}

Neglect committed by the public against the crime of violence against children is one of the factors of the cessation of cases of violence against children. Because the effects of neglect are continuing violence against children until sometimes it leads to loss of life. The greater impact is that children who are victims of violence in their childhood have a great opportunity to do what they experience for others. This certainly will not break the chain of violence against children. To prevent the occurrence of violence against children, care is needed from the surrounding community, the surrounding community has an obligation to provide protection for children. Regarding the omission of violence against children itself has been regulated in Article 78 of the Child Protection Act, whereby every person who omits violence against children is convicted with a maximum imprisonment of 5 (five) years and / or a maximum fine of $\mathrm{Rp} 100$ million. However, so that the omission of violence against children does not occur often and eliminates the assumption that violence perpetrated by parents against their children is a domestic affair that cannot be interfered with by others, it is necessary to have socialization related to the law that must be addressed and reach the community.

\section{BIBILIOGRAPHY}

Books:

Abu Huraerah, 2012, Kekerasan Terhadap Anak, Nuansa Cendekia, Bandung;

Achmad Sulchan, Zakki Mubarok, The Roles Of Investigator In Implementing Diversion On Children Criminal Action, International Journal of Law Reconstruction, Volume II, Issue 1, March 2018;

Ahmad Rofiq, Hari Sutra Disemadi, and Nyoman Serikat Putra Jaya, Criminal Objectives Integrality in the Indonesian Criminal Justice System, AlRisalah 19, no. 2 (December 16, 2019);

Andi Aina Ilmih, Kami Hartono, Ida Musofiana, Legal Aspects Of The Use Of Digital Technology Through Sharia Online Transactions In Traditional Markets In Increasing Community Economy, International Journal of Law Recontruction, Volume 3, Issue 1I, September 2019; 
Andri Winjaya Laksana, Sisca Dyah Octaviani, Implementation Of Law Enforcement Against Crime With Small Motive Patterned Restorative Justice In Police Sector Gayamsari Of Semarang City, International Journal of Law Recontruction, Volume III, Issue 1, March 2019;

Andrie Irawan, Batasan Penelantaran Rumah Tangga Dalam Perspektif Hukum Kekerasan Dalam Rumah Tangga Dan Hukum Perkawinan Indonesia, JURNAL Hukum Responsif 7, no. 2 (2019);

Asla De Vega, Hapidin Hapidin, and Karnadi Karnadi, Pengaruh Pola Asuh Dan Kekerasan Verbal Terhadap Kepercayaan Diri (Self-Confidence), Jurnal Obsesi : Jurnal Pendidikan Anak Usia Dini 3, no. 2 (2019);

Ayu Setyaningrum and Ridwan Arifin, Analisis Upaya Perlindungan Dan Pemulihan Terhadap Korban Kekerasan Dalam Rumah Tangga (KDRT) Khususnya Anak-Anak Dan Perempuan, JURNAL MUQODDIMAH: Jurnal Ilmu Sosial, Politik Dan Hummaniora 3, no. 1 (2019);

Dewi Eko Wati and Intan Puspitasari, Kekerasan Terhadap Anak, Penanaman Disiplin, Dan Regulasi Emosi Orang Tua, Jurnal VARIDIKA 30, no. 1 (2018);

Eva Harianti and Nina Siti Salmaniah, Faktor-Faktor Penyebab Terjadinya Kekerasan Orang Tua Terhadap Anak, JPPUMA Jurnal Ilmu Pemerintahan Dan Sosial Politik Universitas Medan Area 2, no. 1 (2014);

Fransiska Novita Eleanora and Andang Sari, Eksistensi Lembaga Perlindungan Saksi Dan Korban Dalam Memberikan Perlindungan Terhadap Anak Korban Eksploitasi Seksual," Supremasi Hukum: Jurnal Penelitian Hukum 28, no. 2 (2019);

Islamia Ayu Anindia, Perlindungan Hukum Terhadap Perdagangan Anak Dengan Modus Pernikahan Dalam Perspektif Viktimologis, Litigasi 19, no. 1 (2019);

Laurensius Arliman.S, Perlindungan Hukum Terhadap Anak Yang Tereksploitasi Secara Ekonomi Di Kota Padang, Arena Hukum 9, no. 1 (2016);

Nunuk Sulisrudatin, Meninjau Kasus Kekerasan Terhadap Anak Oleh Orangtuanya Dari Segi Kriminologis, Jurnal Ilmiah Hukum Dirgantara 6, no. 1 (2015);

Nurini Aprilianda, "Perlindungan Anak Korban Kekerasan Seksual Melalui Pendekatan Keadilan Restoratif," Arena Hukum 10, no. 2 (2017);

Pusat Bahasa, 2008, Kamus Bahasa Indonesia, Pusat Bahasa Departemen Pendidikan Nasional, Jakarta;

Ria Juliana and Ridwan Arifin, Anak Dan Kejahatan (Faktor Penyebab Dan Perlindungan Hukum), Jurnal Selat 6, no. 2 (2019); 
Rini Fitriani, Peranan Penyelenggara Perlindungan Anak Dalam Melindungi Dan Memenuhi Hak-Hak Anak, Jurnal Hukum Samudra Keadilan 11, no. 2 (2016);

Sarno Setiawan et al., Community Empowerment on Establishment of FriendlyVillage for Women and Children, Indonesian Journal of Advocacy and Legal Services 1, no. 1 (2019);

Tedy Sudrajat, "Perlindungan Hukum Terhadap Hak Anak Sebagai Hak Asasi Manusia Dalam Perspektif Sistem Hukum Keluarga Di Indonesia," Kanun: Jurnal Ilmu Hukum 3, no. 2 (2011);

Thathit Manon Andini, Identifikasi Kejadian Kekerasan Pada Anak Di Kota Malang, Jurnal Perempuan Dan Anak 2, no. 1 (2019); 